\title{
Commuting Mobility as Risk Factor for Dengue Hemorrhagic Fever in Sleman Regency, Yogyakarta, Indonesia
}

\author{
Tri Wulandari Kesetyaningsih* ${ }^{\star 1}$, Siti Fajrini Amir $^{2}$, Yeni Rahma Desty ${ }^{2}$ \\ ${ }^{1}$ Department of Parasitology, Faculty of Medicine and Health Science, Muhammadiyah \\ University Yogyakarta, Indonesia \\ ${ }^{2}$ Faculty of Medicine and Health Science, Muhammadiyah University Yogyakarta, Indonesia \\ *Corresponding author, email: tri_wulandari@umy.ac.id
}

Received: 28/06/2019; published: 29/09/2020

\begin{abstract}
Background:In Indonesia, there has been a change in the age group of dengue hemorrhagic fever (DHF) patient population from children to adults since 1998. It raises the suspicion that an infection occurs not only in residential area but also from other places as a result of human mobility. Research on the role of people mobility as a risk factor for dengue incidence yielded different results. This study aims to reveal the relationship between human mobility and the incidence of dengue. Method: This is a case-control study that involved 276 respondents; 138 were sufferers (case group) while the other 138 respondents were non-sufferers (control group). The sample size was determined by using purposive sampling. Patient's data and their addresses were obtained from Sleman Regency Health Office while the control group was patient's neighbors. The people mobility data were obtained by conducting questionnaires that were divided into three categories, namely low, moderate, and high for commuting mobility and two categories, namely traveling outside and inside province for circular mobility. Chi-square analysis was used to determine whether mobility was a risk factor for DHF. Results:The result showed that commuting mobility was correlated with the DHF incidence $(p=0.001)$ where the high mobility of 3.169 times raised the risk of DHF incidence (OR $3.169 ; 95 \% \mathrm{Cl}: 1.690-5.944$ ) more than the low mobility. However, the DHF incidence was not correlated with moderate mobility $(p=0,821)$. Furthermore, traveling outside the Yogyakarta Province reduced the risk by 6.175 times than non-traveling activity ( $p=0.000$; OR 6.175; 95\% Cl: 2.759-13.822). Conclusion: The commuting mobility outside the village is a risk factor of DHF. Meanwhile, traveling outside Yogyakarta Province did not cause any risk for DHF and it instead tended to reduce the risk.
\end{abstract}

Keywords: dengue hemorrhagic fever;circular mobility;commuting mobility; risk factor

Copyright $\odot 2013$ Universitas Ahmad Dahlan. All rights reserved.

1. Introduction

Since 1998, there has been a change in the age group of dengue hemorrhagic fever (DHF) patient population from children to adults in Indonesia (1) and in Thailand (2). This phenomenon raised the suspicion that infection occurs not only in residential home but also in other places. Thus, there is a possibility of population mobility being a risk factor DHF. High human mobility will increase the spreading of dengue fever either from human or vector (3).

Some studies showed that there was basically a role of human mobility in the incidence of dengue, but the results varied between regions. Research in Australia showed that mobility influenced the incidence of $\operatorname{DHF}(4)$.

Meanwhile, research in Singapore showed that the incidence of DHF was not affected by migrants from other dengue-endemic countries. Rather, it was considered as the impact 
of urbanization and population growth (5). Research in Pakistan showed that during the transmission season, people who had high mobility were at risk of getting infected with dengue (6). Research in Brazil showed that population mobility was related to the incidence of DHF not only during holiday or vacation but also during regular commuting mobility (7).

The result of the research above showed that types of mobility were associated with dengue occurrences whose causes varied in different regions. Although the traveling distance differs between regions, traveling to areas of higher endemic can affect the incidence of dengue both originating from abroad and between endemic areas within one country. The aspect of time during the traveling season is also important to consider in identifying the influence of mobility on the incidence of dengue.

Most people who are involved in commuting mobility aretraders(8), employees(9), and students(10).There were $14.56 \%$ of workers in Sarbagita (Denpasar, Bali, Gianyar, and Tabanan) in 2014 who worked outside their regency and and commuted to their workplace (11). Meanwhile, most students in Ecuador did passive commuting mobility by cars (12). There is no research on student commuting mobility behavior in Indonesia yet.

Sleman Regency is part of Yogyakarta Province which has relatively high dengue cases. It ranked third after Bantul Regency and Yogyakarta City in 2017 with 427 cases (13). Time-series observation on the incidence of dengue in Sleman in 2008-2013 showed fluctuating yet increasing trend (14). Commuting mobility might play a role in dengue incidence in Sleman Regency considering that Sleman Regency is adjacent to the highest endemic area of dengue in Yogyakarta Province, namely Yogyakarta City. It is a destination for job seekers and students in the surrounding area including Sleman Regency. Therefore, commuters have a high possibility to get infected with dengue from Yogyakarta City.

This study aims to analyze the relationship between the mobility of people and the incidence of dengue through a case-control study. This study used a variable distance from residence to workplace or school as a variable that represented a person's commuting mobility. The farther the distance between the house and the workplace or school inside Yogyakarta Province is, the higher the score will be. Traveling outside Yogyakarta Province is included in the category of circular mobility, not commuting mobility. The results of the study are expected to provide information about the role of the population's daily mobility in the incidence of dengue especially in Yogyakarta Province. By knowing the role of commuting mobility in the incidence of dengue, efforts can be made to reduce the risk of dengue infection for commuters.

\section{Methods}

This study is an observational research using a case-control design with the sufferer and non-sufferer of dengue hemorrhagic fever as the subjects. We used purposive sampling method and formula of Lemeshow, 1997 to determine the sample size. This study involved 276 respondents; 138 respondents were sufferers as the case group, and 138 respondents were non-sufferers as the control group. Patients were determined based on the names and addresses of patients on the DHF record from the District Health Office of Sleman and the data from Puskesmas. The secondary data in the District Health Office and Puskesmas were obtained from the reports of residents with evidence of diagnosis from the hospital where the patient was being treated. The diagnosis of DHF was taken from the WHO (1997) where patients were diagnosed based on the increase in hematocrit $>20 \%$ with thrombocytopenia $(<100,000 / \mathrm{mL})$.

The sufferers-respondents' data were obtained from the record of DHF patients in 2013 from Sleman Regency Health Office. Patients with unclear addresses were excluded from the participant selection. The control group was the neighbors of the suffering patients who had almost similar characteristics. The participants livein Gamping and Godean subdistrict of SlemanRegency, Yogyakarta, Indonesia. Gamping sub-district represented urban 
dengue-endemic areas, while Godean sub-district represented the sub-urban dengueendemic area.

Based on the length of time, mobility is divided into two categories including permanent and temporary or circular mobility. The mobility defined in this study is both commuting and circular mobility. Commuting mobility is represented by the range of the distance between residential home and the workplace or school while circular mobility is represented by traveling outside the Yogyakarta Province. The data on commuting mobility and circular mobility were obtained from questionnaires and then divided into three categories namely low, moderate, and high mobility. Low category is when the respondent does not have a daily routine outside the house such as housewives, pensioners, and toddlers who have not attended school. Medium category is when the respondent has a daily routine outside the house but still inside the village. Meanwhile, high category is when the respondent has daily routine activities outside the house particularly outside the village. Daily activities outside the house were represented by working and school activities .Therefore, the address of the school or workplaceis were required to get the information regarding the mobility category. The circular mobility in this study is represented by traveling outside Yogyakarta Province. Traveling outside Yogyakarta Province was included in the study to demonstrate the potential of getting infection from outside Yogyakarta Province.

The research was approved by the Health Research Ethics Commission of the Faculty of Medicine and Health Sciences, Muhammadiyah University Yogyakarta as proved by letter no. 466/EP-FKIK-UMY/XI/2015. We also obtained a permit from the Sleman Regency Government (letter no. 070 / Bappeda / 3703/2015) in collecting the necessary data.

\section{Results and Discussion}

\subsection{Results}

The total participants in this study were 276 people where the case and control group consisted of 138 participants respectively. Table 1 describes the characteristics of respondents based on gender, age, and activity status. Table 1 shows that there were more male DHF sufferers than female DHF sufferers (60.1\%). In terms of age, DHF attacked adults $(52.9 \%)$ more than children $(47.1 \%)$, and there was no incidence of dengue in the age of $>50$-year-old group. In terms of activity status, dengue sufferer was more common in students $(66.7 \%)$.

Table 1.Distribution of Respondents in Sleman Regency Based

\begin{tabular}{lcc}
\hline \multicolumn{1}{c}{ Category } & $\begin{array}{c}\text { Case } \\
\text { Frequency (\%) }\end{array}$ & $\begin{array}{c}\text { Control } \\
\text { Frequency (\%) }\end{array}$ \\
\hline Sex & & \\
Male & $83(60.1)$ & $53(39.1)$ \\
Female & $55(39.9)$ & $84(60.9)$ \\
Age & & \\
515year & $65(47.1)$ & $63(45.7)$ \\
15-50 year & $73(52.9)$ & $75(54.3)$ \\
$>50$ year & 0 & 0 \\
Activity & & $85(61.6)$ \\
Student & $92(66.7)$ & $28(20.3)$ \\
Worker & $35(25.4)$ & $25(18.1)$ \\
Unemployed & $11(7.9)$ & \\
\hline
\end{tabular}

The analysis bivariate shows that there was a significant difference between the high mobility and the low mobility $(p=0.001)$ where high mobility had as much as 3.169 (OR3.169; 95\%Cl:1.690-0.499) compared to low mobility. However, high mobility was not significantly different compared to moderate mobility $(\mathrm{p}=0.821)$. (Table 2$)$. 
The result of the analysis shows that traveling outside Yogyakarta Province could reduce the risk by 6.175 times than not traveling outside Yogyakarta Province $(p=0.000$; OR 6.175; 95\% Cl: 2.759-13.822). Based on the data from the questionnaire, the destination travel out of Yogyakarta Province included various cities in Indonesia.(Table 2).

Table 2.The result of analysis bivariate of commuting mobility and circular mobility in Sleman Regency Yogyakarta Province Indonesia

\begin{tabular}{|c|c|c|c|c|c|c|c|}
\hline \multirow{3}{*}{ Category } & \multicolumn{4}{|c|}{ DHF } & \multirow{3}{*}{$\mathbf{N}$} & \multirow{3}{*}{$\begin{array}{l}\mathrm{p}- \\
\text { value }\end{array}$} & \multirow{3}{*}{ OR (95\%Cl) } \\
\hline & \multicolumn{2}{|c|}{ Yes } & \multicolumn{2}{|c|}{ No } & & & \\
\hline & $\mathrm{n}$ & $\%$ & $\mathbf{n}$ & $\%$ & & & \\
\hline $\begin{array}{l}\text { Commuting Mobility } \\
\text { Low Mobility }\end{array}$ & 18 & 13.04 & 46 & 33.33 & 64 & 0.001 & $\begin{array}{c}3.169 \\
(1.69-5.944)\end{array}$ \\
\hline Moderate Mobility & 29 & 21.01 & 21 & 15.22 & 50 & 0.821 & $\begin{array}{c}0.930 \\
(0.494-1.749)\end{array}$ \\
\hline High Mobility & 91 & 65.94 & 71 & 51.45 & 162 & & Comparator \\
\hline \multicolumn{8}{|l|}{ Circular Mobility } \\
\hline $\begin{array}{l}\text { Traveler outside } \\
\text { province }\end{array}$ & 8 & 5.80 & 38 & 27.54 & 46 & \multirow[t]{2}{*}{0.000} & \multirow{2}{*}{$\begin{array}{c}6.175 \\
(2.759-13.822)\end{array}$} \\
\hline $\begin{array}{l}\text { Non-traveler outside } \\
\text { province }\end{array}$ & 130 & 94.20 & 100 & 72.46 & 230 & & \\
\hline
\end{tabular}

\subsection{Discussion}

The distribution of dengue patients based on sex, age, and activity shows that most dengue sufferers were male (60\%) in productive age (16-50 years; $52.9 \%$ ) and those whose profession were students (66.7\%). The data does not show significant differences from the result of research on dengue infection based on gender in Bali (16). Furthermore, the research conducted in China showed that there were slightly more DHF cases in males than in females (17). However, studies in Taiwan, based on 2007-2011 data, showed that the incidence of DHF in women was slightly higher (51.3\%) than men (48.7\%)(18).

In terms of age, people in productive age were more infected with dengue. It is likely because the mobility of the productive age group is higher than children or elderly people. The increase in the percentage of DHF adult patients in is probably related to the possibility of the role of high mobility in productive-age people (19). The most common type of activity in DHF patients in this study was school activity (66.7\%)(Table 1). This result indicates that commuters whose frequent activity is going to school are the group that needs more attention in the effort of preventing the spread of dengue disease especially in Sleman Regency.

This study suggests that commuting mobility is a risk factor for dengue incidence in Sleman by using case-control study. People who have daily routine activities outside the house particularly outside the village (high commuting mobility) have a risk of 3.169 times greater than people who do not. In this study, high commuting mobility represents the activities outside the territory of the village from 6 to a maximum of 24 hours such as activities related to work or school. These results suggest that the possibility of dengue infection occurs not only at home but also at school or workplace. The data from the interview show that $37.54 \%$ of commuters go to work or school in Yogyakarta City. This is in line with another study which stated that people in productive age commute to school (20) or work (21). Yogyakarta City was the highest endemic area in Yogyakarta Province in 2016 (341.97/100,000 population)(13) and that commuters were most likely infected with dengue originating from Yogyakarta City.

Studies on the relationship between the mobility of people and dengue incidents have shown consistent results. Telle et.al. showed a similar result where mobility was a risk factor for the occurrence of dengue in India (22), in Singapore by Struchiner (5), and also in 
Indonesia especially in Tangerang by Siregar (23). However, these studies did not specify the type of mobility.

The result of this study shows that circular mobility has a negative correlation with dengue incidence. People who do not travel outside the Yogyakarta Province is at the risk of dengue by 6.175 times than those who do. It indicates that the incidence of dengue in Sleman Regency did not come from outside the province but originated from other regions within Yogyakarta Province. This result is similar to the results of the research in Singapore which revealed that the incidence of DHF was not related to the number of foreigners from dengue-endemic areas outside Singapore (5). Meanwhile, research in China found that urban villages were considered as the center of the spread of Dengue Fever (DF) where the dengue cases came in and out of the area during an epidemic (24). In this case, Sleman Regency might get the infection of DHF from Yogyakarta City as most of the Sleman Regency areas are agglomerations of Yogyakarta City.

The evidence showing that commuting mobility influences the incidence of dengue in Sleman Regency while circular mobility is negatively correlated with DHF reinforces the idea that interregional influences within Yogyakarta Province may cause the incidence of dengue in Sleman Regency. In other words, as the data shows that $43.68 \%$ of high mobility respondents commuted to Yogyakarta City, the possibility of dengue cases in Sleman Regency is considered to be originating from Yogyakarta City. However, this still needs further research on the study of spatial correlation.

This study identified the commuting mobility based on daily activities and circular mobility including traveling activities outside Yogyakarta Province. Data were obtained through questionnaires, and we did not use a spatial approach. However, the results of this study have contributed to enriching the information that commuting mobility increases the risk of dengue fever while circular mobility outside Yogyakarta Province reduces the risk of dengue in Sleman Regency. Thus, the results of this study contribute to providing essential information in the efforts to reduce the risk of commuters from getting infected by dengue. In addition, it is necessary to conduct further research in the direction of population mobility by using a spatial approach.

\section{Conclusion}

It can be concluded that daily routine activities outside the house such as traveling outside the village increase the risk of dengue infection while traveling outside Yogyakarta Province reduces the risk of dengue infection in Sleman Regency. Furthermore, commuting mobility which is the main risk factor for a dengue infection is likely related to school activities.

\section{References}

1. Karyanti MR, CunoUSPM, Kusriastuti R, Hadinegoro SR, MaroeskaRM, and Hans $\mathrm{H}$, et al. The Changing Incidence of Dengue Haemorrhagic Fever in Indonesia: A 45-Year RegistryBased Analysis. BMC Infectious Diseases. 2014;14(412):1-7.

2. Tangsathapornpong A,Puriburt $C$, and Bunjoungmanee P. Epidemiology of Dengue at Thammasat University Hospital during 2006-2015. Southeast Asian J Trop Med Public Health. 2017;48(1):39-46.

3. Barmak DH, Dorso CO, Otero M.Modelling dengue epidemic spreading with human mobility. Physica A: Statistical Mechanics and its Applications.Elsevier. 2016;447:129-140.

4. Kim, M., Painib, D. and Jurdaka, R. Modeling stochastic processes in disease spread across a heterogeneous social system. PNAS. 2019;116(2):401-406.

5. Struchiner CJ, Rocklöv J, Wilder-Smith A, Massad E. Increasing Dengue Incidence in Singapore over the Past 40 Years: Population Growth, Climate and Mobility. PLoS ONE. 2015;10(8):1-14.

Disease Prevention and Public Health Journal

Volume 14, Issue 2, September 2020: $58 \sim 63$ 
6. Wesolowskia A, Qureshic, Bonid MF, Sundsøyc PR, Johanssonb MA, Rasheedg SB, Engø-Monsenc K, Buckeea CO.Impact of human mobility on the emergence of dengue epidemics in Pakistan. PNAS. 2015;112(38):11887-11892.

7. FalcoÂn-Lezama JA, Santos-Luna R,RomaÂn-PeÂrez S, MartõÂnez-Vega RA, HerreraValdez MA, Kuri-MoralesAÂ F, et al. Analysis of spatial mobility in subjects from a Dengue endemic urban locality in Morelos State, Mexico. PLOS ONE.2017;12(2):1-19.

8. Bräuchler,B. Changing patterns of mobility, citizenship and conflict inIndonesia. Social Identities.2017;23(4):446-461.

9. Sche'eleS, and Andersson G. City attraction and commuter mobility in urban Sweden: An analysis based on longitudinal population data. Urban Studies. 2018;55(9):1875-1903.

10. Cisani, M.High school commuters. Sustainability education onstudents' mobility behaviours and perceptions of theireveryday landscape.Journal of Research and Didactics in Geography. 2017;2(6):55-68.

11. Putrawan IW, dan Sari NP. Mobilitas Non Permanen Menjadi Pilihan Sebagian Pekerjadalam Menghadapi Himpitan Ekonomi di Wilayah Denpasar,Badung, Gianyar dan Tabanan Provinsi Bali 2014. Piramida, 2015;11(2):59-67.[Indonesia]

12. Barranco-Ruiz Y, Guevara-Paz AX, Ramírez-Vélez R, Chillón P and Villa-González E. Mode of Commuting to School and Its Association with Physical Activity and Sedentary Habits in Young Ecuadorian Students. Int. J. Environ. Res. Public Health.2018;15(12):1-12.

13. Dinkes Provinsi DIY. Profil Kesehatan DIY tahun 2017. Available 19 September 2019 at http://www.depkes.go.id/resources/download/profil/PROFIL_KES_PROVINSI_2017/14_DI Y_2017.pdf [Indonesia]

14. Kesetyaningsih TW, Andarini S., Sudarto and Pramoedyo H., 2018. Determination of Environmental Factors Affecting Dengue Incidence in Sleman District, Yogyakarta, Indonesia. Afr., J. Infect. Dis. 2018;12(1):13-25.

15. BPS of Sleman Regency. 2018. Sleman Regency in Figures 2018.<https://slemankab.bps.go.id/publication/2018/08/16/aa71d0b4c2f5a3a79bbe9583/ka bupaten-sleman-dalam-angka-2018.html> Accessed 4 March 2019.

16. Saraswati LPC, dan Mulyantari NK. Prevalensi Demam Berdarah Dengue (DBD) Primer dan Sekunder Berdasarkan Hasil Pemeriksaan Serologis di Rumah Sakit Balimed Denpasar. MedikaUdayana. 2017;6(8):1-6.

17. Sun J, Lua L, Wua H, Yanga J, Xua L, Sangc S, Liua Q. Epidemiological trends of dengue in mainland China, 2005-2015. International Journal of Infectious Diseases; 2017;57:8691.

18. Chang C-J, Chen CS, Tien C-J, Lu M-R. Epidemiological, clinical and climatic characteristics of dengue fever in Kaohsiung City, Taiwan with implication for prevention and control. PLOS ONE, 2018;13(1):1-15.

19. Ratanawong $P$, Kittayapong $P$, Olanratmanee $P$, Wilder-Smith $A$, Byass $P$, Tozan $Y$, et al. Spatial Variations in Dengue Transmission in Schools in Thailand. PLOS ONE. 2016;11(9): $1-16$.

20. Cisani, M.High school commuters. Sustainability education on students' mobility behaviours and perceptions of their everyday landscape. Journal of Research and Didactics in Geography (J-READING), 2017;6(2):55-68.

21. Priyono, CA.,Umrotun, AIW., and Suliadi S. Statistical Mobility Pattern Of Solo-Yogyakarta Commuter Workers by Prambanan Express Train. International Journal of Scientific \& Technology Research, 2019;8(9):139-146

22. Telle O, Vaguet A, Yadav NK, Lefebvre B, Daudé E, Paul RE, et al. The Spread of Dengue in an Endemic Urban Milieu-The Case of Delhi, India. PLOS ONE, 2016;11(1):1-17.

23. Siregar D, Djadja IM, and Arminsih R. Analysis of the Risk Factors of Dengue Hemorrhagic Fever (DHF) in Rural Populations in Panongan Subdistrict, Tangerang 2016. in The 1st International Conference on Global Health. KnE Life Sciences. 2017:119-128.

24. Ren H, Wu W, Li T, Yang Z. Urban villages as transfer stations for dengue fever epidemic: A case study in the Guangzhou, China. PLoSNegl Trop Dis. 2019;13(4):1-17. 